\title{
Enzyme-assisted extraction of phenolic compounds from murucizeiro leaves (Byrsonima crassifolia)
}

Extração de compostos fenólicos de folhas do murucizeiro (Byrsonima crassifolia) assistida por enzimas

J. A. R. de Oliveira ${ }^{1, *}$; A. Komesu²; L. H. da S. Martins ${ }^{3} ;$ H. Rogez ${ }^{4}$; R. da S. Pena $^{3}$

${ }^{1}$ Faculdade de Nutrição, Universidade Federal do Pará, 66075-110, Belém, PA, Brasil.

${ }^{2}$ Faculdade de Engenharia Química-UNICAMP, Cidade Universitária Zeferino Vaz, 13083-852, Campinas - SP Brasil

${ }^{3}$ Faculdade de Engenharia de Alimentos, UFPA, 66075-110, Belém, PA, Brasil.

${ }^{4}$ Faculdade de Biotecnologia, UFPA, 66075-110, Belém, PA, Brasil.

*Johnattrocha@yahoo.com.br

(Recebido em 31 de março de 2020; aceito em 27 de maio de 2020)

The aim of this work was to evaluate the enzyme-assisted extraction of phenolic compounds from murucizeiro leaves (Byrsonima crassifolia) employing response surface methodology (RSM), in order to determine the best extraction conditions. The chemical composition of the leaves and characteristics of the enzymes were determined. The independent variables were temperature $\left(19\right.$ to $\left.70^{\circ} \mathrm{C}\right), \mathrm{pH}(2.4$ to 7.5$)$ and reaction time (19 to 220 minutes). A conventional and optimized triple extraction with organic solvents was used as control. As result to solvent extraction was observed $73.28 \mathrm{mg}$ of gallic acid equivalents (GAE) $\mathrm{g}^{-1}$ $\mathrm{DM}$, while under the best condition for enzyme-assisted extraction (temperature: $60^{\circ} \mathrm{C} ; \mathrm{pH}: 4.5$; and time: $220 \mathrm{~min}$ ), the concentration was $90.65 \mathrm{mg} \mathrm{GAE} \mathrm{g}^{-1}$. The independent variables significant were: temperature, $\mathrm{pH}$ and log time at the linear level and temperature at the quadratic level. A similar methodology could be encouraged for other natural products rich in phenolic compounds.

Keywords: Byrsonima crassifolia, phenolic compounds, Response surface methodology.

O objetivo deste trabalho foi avaliar a extração de compostos fenólicos de folhas do murucizeiro (Byrsonima crassifolia) auxiliada por enzimas, empregando metodologia de superfície de resposta (RSM), a fim de determinar as melhores condições de extração. A composição química das folhas e as características das enzimas foram determinadas. As variáveis independentes foram temperatura $\left(19\right.$ a $\left.70^{\circ} \mathrm{C}\right), \mathrm{pH}(2,4$ a 7,5$)$ e tempo de reação (19 a 220 minutos). Uma extração tripla convencional e otimizada com solventes orgânicos foi usada como controle. Como resultados para a extração com solvente foi observado $73,28 \mathrm{mg} \mathrm{de}$ equivalentes de ácido gálico (GAE) $\mathrm{g}^{-1}$, enquanto que na melhor condição para a extração assistida por enzima (temperatura: $60^{\circ} \mathrm{C}$; pH: 4,5; e tempo: $220 \mathrm{~min}$ ), a concentração foi de 90,65 mg GAE g-1. As variáveis independentes significativas foram: temperatura, $\mathrm{pH}$ e tempo de log no nível linear e temperatura no nível quadrático. Uma metodologia semelhante deve ser incentivada para outros produtos naturais ricos em compostos fenólicos.

Palavras-chave: Byrsonima crassifolia, compostos fenólicos, metodologia de superfície de resposta.

\section{INTRODUCTION}

Phenolic compounds are phytochemicals produced as secondary metabolites in a variety of daily-consumed vegetables. They present important functions to the plant: insect protection, drought season resistance and ultraviolet protection [1]. Such aspects arouse interest in these compounds and its properties at consumption. The Amazon region offers great potential in supplying phenolic enriched vegetables. Byrsonima crassifolia is one of these species, knowed in Brazil as murucizeiro, and has as main products the fruit and leaves, which has high antioxidant capacity [2].

Phenolic compounds are obtained through vegetable matrix consumption or a variety of forms after extraction and application in pharmaceutic, cosmetic or food production. However, the 
extraction processes may need more complexity depending on its purposes, and the extracts quality can be critical for future applications [3]. Therefore, the extraction step is fundamental to obtain these compounds on desirable quality and quantity.

Traditional extraction processes include chemical agent used as organic solvents [4], which can be efficient in some cases, but are often environmentally aggressive and demands strict control of solvent polarity, time and extraction temperature, which can lead to antioxidant compounds loss after long extraction periods [5]. Therefore, there have been growing interest in developing new extraction methods, especially green extractions, which allows alternative solvents use, reducing energy consumption and enabling the use of renewable natural products [6].

Enzyme-assisted extraction is based on the fact that phenolic compounds on vegetable cells accumulate on two places: (i) the cell wall for flavonoids, esterified ferrulic acids and lignins, and (ii) the vacuole for soluble phenolic compounds and their derivatives [7]. During extraction, enzymes such as cellulases, hemicellulases, pectinases and others, varying according to the plant matrix composition, disrupt these cellular structures and release the compounds of interest $[8,9]$.

These extraction method received special attention for increasing release and recovery of phenolic compounds covalently or non-covalently bounded to the cell wall structure [9-11], besides reducing both energy cost and toxicity of the obtained extracts. It can be used as an alternative to the release of bioactive components from plant materials, due to its advantages of environmental compatibility, high efficiency, and easy operation processing [12].

Many theoretical and empirical models have been developed to predict enzymatic hydrolysis [13]. For this purpose, it is important the knowledge of the decisive intrinsic factors on the processes, such as: $\mathrm{pH}$, temperature, time and enzyme/raw material ratio [14]. Based on the Michaelis-Menten model, important parameters such as: maximum velocity (Vmax) and MichaelisMenten constat $(\mathrm{Km})$ should be observed, in order to obtain efficient kinetics on the enzymatic biodigestion [13].

Enzymatic preparations using pectinases and cellulases are already a reality on fruit processing, and have showed good results in polysaccharides degradation and phenolic compounds release on grape marc $[15,16]$, apple juice and gooseberry. Depending on the vegetable matrix this process can demand an enzymatic association or individual enzymes [14].

The leaves of the murucizeiro have been widely studied, but all studies are based on extracts obtained as use of organic solvents [17], which present all the known technological restrictions. Thus, this work aims to evaluate, for the first time, the use of an enzyme cocktail to extract the phenolic compounds from the leaves of the murucizeiro, proposing a new method directed to this raw material with the obtaining of extracts rich in phenolic compounds and without inconveniences related to the use of organic solvents.

\section{MATERIAL AND METHODS}

\subsection{Material}

The $B$. crassifolia leaves $(5 \mathrm{~kg}$ ) were collected from the Guamá Campus of the Federal University of Pará (Belém, Brazil). Specie identification of the analyzed specimen was performed at the Museu Emilio Goeldi (Belém, Brazil) under registration No. 130939.

Leaves were dried in an incubator with air circulation at $50^{\circ} \mathrm{C}$ triturated in a grinder (type, Willye; model, TE-650; Tecnal, São Paulo, Brazil), and sieved. The fraction used was that passed through in 20 -mesh sieve $(0.84 \mathrm{~mm})$ and was retained on a 28 -mesh sieve $(0.6 \mathrm{~mm})$. The product was stored at $-20{ }^{\circ} \mathrm{C}$ until analysis.

\subsection{Methods}

Enzymes used in the experiments were as follows: cellulase from Aspergillus niger, protease from Bacillus licheniformis (both from Fluka, Buchs, Switzerland), and hemicellulase (xylanase) and pectinase (polygalacturonase) from A. niger (both from Sigma, St. Louis, MO).

The leaves of $B$. crassifolia leaves were analyzed to: moisture, analyzed in a vacuum incubator at $70^{\circ} \mathrm{C}$; ashes, obtained by calcination of samples at $550^{\circ} \mathrm{C}$; protein content, obtained by micro- 
Kjeldahl technique, with a nitrogen-protein conversion factor of 6.25 ; lipid content, extraction in Soxhlet; total dietary fiber (TDF) and insoluble dietary fiber (IDF), obtained by enzymaticgravimetric method [18]; soluble dietary fiber (SDF), calculated as the difference between TDF and IDF; cellulose content, obtained by using the method by Silva and Queiroz (2002) [19]; hemicellulose content, obtained by the difference of fractions calculated by analyzing neutral detergent fiber (NDF) and acid detergent fiber (ADF) contents by using the methodology described by Van Soest (1990) [20]; lignin content [19]; and pectin content, obtained by extraction according to McCready and McComb (1952) [21].

The Solvent extraction was performed according to Silva et al. (2007) [17] at $58^{\circ} \mathrm{C}$ during 45 $\min$. The extraction solutions used were as follows: 1- extraction, acetone:methanol (70:30, v:v); 2- extraction, methanol:water (70:30, v:v); and 3- extraction, methanol:water:acetic acid (50:40:10, $\mathrm{v}: \mathrm{v}: \mathrm{v})$ and finally mixed.

Cellulase activity was determined according to Ghose (1987) [22], by measuring the initial release rate of reducing sugars from a cellulose $2 \%$ standard solution (Sigma), using the 3,5dinitrosalicylic acid (DNS) method [23]. Xylanase activity was determined according to Bailey et al. (1992) [24], using a 2\% standard solution of xylan (Sigma) Polygalacturonase activity was determined by the release of reducing groups from a $2 \%$ standard solution of low methoxylation citrus pectin (Sigma) [25]. Protease activity was determined from a $2 \%$ standard solution of soy protein isolate (Integral Médica, Embú-Guaçú, Brazil) [26].

For enzymatic extraction, $0.2 \mathrm{~g}$ of powdered $B$. crassifolia leaves were weighed in conical amber flasks $(30 \mathrm{~mL})$. The Extraction solution $(4 \mathrm{~mL})$ in the buffer evaluated containing: cellulase (3.81 $\left.\mathrm{IU} . \mathrm{g}^{-1}\right)$, xylanase $\left(2.45 \mathrm{IU}_{\mathrm{g}} \mathrm{g}^{-1}\right)$, polygalacturonase $\left(2.24 \mathrm{IU} . \mathrm{g}^{-1}\right)$, and protease $\left(1.02 \mathrm{IU}_{\mathrm{g}} \mathrm{g}^{-1}\right)$ was added in the tubes. The enzymatic extraction of was accomplished in a thermostatically controlled orbital shaker (MARCONI, MA420/315, Brazil) with gentle agitation $(150 \mathrm{rpm}$ ) in the dark. At the end of each extraction, the sample was centrifuged at $4^{\circ} \mathrm{C}$ for $5 \mathrm{~min}$ at $7,000 \mathrm{rpm}$ and the supernatants were removed and frozen at $-10^{\circ} \mathrm{C}$ for analysis. Buffers used were as follows: $\mathrm{pH} 2.4$ (glycine, $0.2 \mathrm{M} \mathrm{HCl}$ ), pH 3.5 (citrate-phosphate, $0.1 \mathrm{M}$ ), pH 5.0 (sodium acetate, $0.05 \mathrm{M}$ ), pH 6.5 (potassium phosphate, $0.05 \mathrm{M}$ ), and $\mathrm{pH} 7.5$ (potassium phosphate, $0.05 \mathrm{M}$ ). Phenolic compounds were determined by the Folin-Ciocalteu colorimetric method [27], adapted by Silva et al. (2007) [17] to spectrophotometer microplates measured at $765 \mathrm{~nm}$ and expressed in $\mathrm{mg} \mathrm{GAE} \mathrm{g}^{-1}$.

\subsection{Statistical methods}

Based on the response surface methodology (RSM), a experimental design was applied. The parameters of the process, identified as independent variables, were evaluated in 5 coded levels ($\alpha,-1,0,+1,+\alpha)$. A full factorial 23 design was used and is showed in the Table 1 , with 8 factorial experiments (combinations between levels -1 and +1$), 5$ axial ( 1 variable at level $+\alpha$ and 2 at 0 , and 1 variable at level $-\alpha$ and 2 at 0 ), and 6 repetitions at the central point. Six additional points were performed, resulting in 25 experiments. The results were analysed with the Statistica 7.0 software (Statsoft Inc.) using analysis of variance (ANOVA) and the Tukey test $(\mathrm{p}<0.05)$ to validate empirical mathematical model generated.

\section{RESULTS AND DISCUSSION}

\subsection{Composition of B. crassifolia leaves}

The characterization was performed with the main objective of identifying the fiber content of the leaves and facilitating the choice of enzymes to be used in the enzymatic extraction. Considering the dry matter values, total fiber content of B. crassifolia leaves $(85.52 \%)$ was much higher than that reported by Esmelindro et al. [28] (14.96-19.95\%) in yerba mate leaves and by Modesti et al. (2007) [29] (21.40\%) in cassava leaves flour. The chemical characterization showed: 9.93\% \pm 0.50 (protein), 3.09\% \pm 0.37 (lipids), $1.43 \% \pm 0.01$ (Ash), $45.99 \% \pm 0.02$ (Cellulose), $26.28 \% \pm 0.25$ (Hemicellulose), $5.62 \% \pm 0.63$ (lignin), $5.11 \% \pm 0.32$ (Pectin). 


\subsection{Statistical analysis of enzymatic extractions}

The concentrations of total phenolic compounds obtained from B. crassifolia leaves by enzymatic extraction under the different conditions of the experimental design, are presented in Table 1.

Table 1. Central composite design setting in original and coded formsa of the independent variables ( $p H$, time and temperature) and experimental results for the total phenolic content of Byrsonima crassifolia leaves.

\begin{tabular}{ccccc}
\hline Run order & Temperature $\left({ }^{\mathbf{C}} \mathbf{C}\right)$ & $\mathbf{p H}$ & Time $(\mathbf{m i n})$ & Total phenolics $^{b}$ \\
\hline $\mathbf{1}$ & $-1(30)$ & $-1(3.5)$ & $-1(60)$ & 55.03 \\
$\mathbf{2}$ & $-1(30)$ & $-1(3.5)$ & $+1(180)$ & 68.01 \\
$\mathbf{3}$ & $-1(30)$ & $+1(6.5)$ & $-1(60)$ & 50.89 \\
$\mathbf{4}$ & $-1(30)$ & $+1(6.5)$ & $+1(180)$ & 52.97 \\
$\mathbf{5}$ & $+1(60)$ & $-1(3.5)$ & $-1(60)$ & 89.47 \\
$\mathbf{6}$ & $+1(60)$ & $-1(3.5)$ & $+1(180)$ & 95.45 \\
$\mathbf{7}$ & $+1(60)$ & $+1(6.5)$ & $-1(60)$ & 69.06 \\
$\mathbf{8}$ & $+1(60)$ & $+1(6.5)$ & $+1(180)$ & 86.25 \\
$\mathbf{9}$ & $-\alpha(19)$ & $0(5.0)$ & $0(120)$ & 35.57 \\
$\mathbf{1 0}$ & $+\alpha(70)$ & $0(5.0)$ & $0(120)$ & 80.71 \\
$\mathbf{1 1}$ & $0(45)$ & $-\alpha(2.4)$ & $0(120)$ & 90.98 \\
$\mathbf{1 2}$ & $0(45)$ & $+\alpha(7.5)$ & $0(120)$ & 55.08 \\
$\mathbf{1 3}$ & $0(45)$ & $0(5.0)$ & $+\alpha(220)$ & 85.98 \\
$\mathbf{1 4}$ & $0(45)$ & $0(5.0)$ & $0(120)$ & 76.43 \\
$\mathbf{1 5}$ & $0(45)$ & $0(5.0)$ & $0(120)$ & 70.23 \\
$\mathbf{1 6}$ & $0(45)$ & $0(5.0)$ & $0(120)$ & 70.24 \\
$\mathbf{1 7}$ & $0(45)$ & $0(5.0)$ & $0(120)$ & 75.11 \\
$\mathbf{1 8}$ & $0(45)$ & $0(5.0)$ & $0(120)$ & 70.01 \\
$\mathbf{1 9}$ & $0(45)$ & $0(5.0)$ & $0(120)$ & 77.02 \\
$\mathbf{2 0}$ & $0(45)$ & $-1(3.5)$ & $+1(180)$ & 89.97 \\
$\mathbf{2 1}$ & $+1(60)$ & $-\alpha(2.4)$ & $+1(180)$ & 85.10 \\
$\mathbf{2 2}$ & $+1(60)$ & $-\alpha(2.4)$ & $0(120)$ & 90.23 \\
$\mathbf{2 3}$ & $+\alpha(70)$ & $-\alpha(2.4)$ & $+1(180)$ & 88.12 \\
$\mathbf{2 4}$ & $+\alpha(70)$ & $-1(3.5)$ & $+\alpha(220)$ & 84.36 \\
$\mathbf{2 5}$ & $+\alpha(70)$ & $-\alpha(2.4)$ & $+\alpha(220)$ & 82.02 \\
\hline
\end{tabular}

${ }^{a}$ Values between brackets are the original forms of the variables; ${ }^{b} \mathrm{mg} \mathrm{GAE} \mathrm{g}^{-1} \mathrm{DM}$.

In Table 2 the Analysis of variance (ANOVA) for the phenolic compounds release yield is summarized. Was verified that the generated mathematical model was significant and predictive, the model passed in the Fisher-test (F-test) of the regression, since the value of the F calculated was greater than the value of $\mathrm{F}$ tabled $(17.18>2.59)$ and also passed in the F-test of the lack of fit, since the $\mathrm{F}$ calculated was less than the F tabled $(7.79<10.05)$. Thus, the mathematical model and response surfaces were generated (Equation 1 and Figure 2). The value of R2 showed that the model explained $91.65 \%$ of the variation of the experimental data, which is desirable, and had a maximum explainable variation of the $98.99 \%$. 
Table 2-Analysis of variance (ANOVA) for the phenolic compounds release.

\begin{tabular}{|c|c|c|c|c|c|}
\hline \multirow[t]{2}{*}{ Source of variation } & \multirow{2}{*}{$\begin{array}{l}\text { Sums of } \\
\text { squares }\end{array}$} & \multirow{2}{*}{$\begin{array}{l}\text { Degree of } \\
\text { freedom }\end{array}$} & \multirow{2}{*}{$\begin{array}{l}\text { Average } \\
\text { Square }\end{array}$} & \multicolumn{2}{|c|}{ F-test (95\%) } \\
\hline & & & & F table & F calculated \\
\hline Regression & 5111.47 & 9 & 567.94 & 17.18 & 2.59 \\
\hline Residual & 495.81 & 15 & 33.05 & & \\
\hline Lack of fit & 439.38 & 10 & 43.94 & 7.79 & 10.05 \\
\hline Pure error & 56.43 & 5 & 11.29 & & \\
\hline Total & 5607.28 & 24 & & & \\
\hline $\begin{array}{c}\% \text { of variation explained } \\
\left(\mathbf{R}^{2}\right)\end{array}$ & \multicolumn{5}{|c|}{$91.16 \%$} \\
\hline $\begin{array}{c}\% \text { of maximum explainable } \\
\text { variation }\end{array}$ & \multicolumn{5}{|c|}{$98.99 \%$} \\
\hline
\end{tabular}

Variables with significant effects $(\mathrm{p}<0.05)$ were as follows: temperature $(\mathrm{L}$ and $\mathrm{Q}), \mathrm{pH}(\mathrm{L})$, and $\log$ time (L). The estimated effect indicates how each factor influenced the studied response; the higher the factor value, the greater was the influence on the response variable, as shown in the Pareto chart (Figure 1).

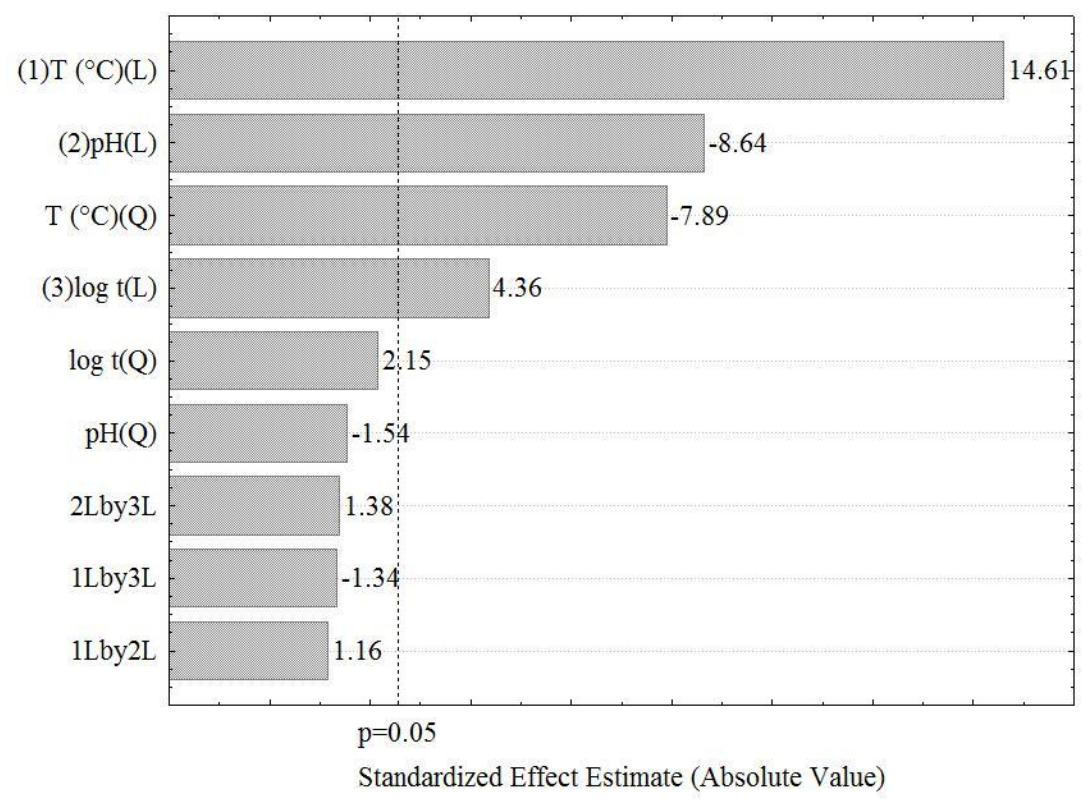

Figure. 1. Pareto charts of the standardised effects for the total phenolic content of Byrsonima crassifolia leaves. T: temperature; $\mathrm{pH}$ : hidrogenionic potential; log $t$ : logarithm of time; L: linear effect; Q: quadratic effect.

According to Figure 1, the linear effect of temperature showed the greatest influence on the content of extracted phenolic compounds. The effect showed a positive value, indicating that the higher the temperature of extraction, the greater the amount of extracted phenolic compounds. This behavior is in agreement with the findings of Escribano-Bailón and Santos-Buelga (2003) [30] for the extraction of polyphenols from food products. These authors attributed this effect to the influence of temperature on the increase in diffusivity.

The quadratic effect of temperature was also significant, but negative, indicating the existence of a maximum point for the effect of this variable on the extraction. The high temperature provided greater kinetic energy to molecules of the reagents, which resulted in increased collisions and a higher yield for the enzymatic extractions [31]. However, high temperatures cause the disruption 
of weak links of enzymes, and its subsequent denaturation reduces hydrolysis and the release rate of the compounds of interest.

The linear effect of $\mathrm{pH}$ showed a negative coefficient, indicating that a more acidic $\mathrm{pH}$ favors the extraction of phenolic compounds. This effect should be primarily because of the acid $\mathrm{pH}$ and not because of enzyme action, since enzymes of the cellulase complex show a reduction of activity at $\mathrm{pH}$ values close to 3.5. The addition of acids to the extraction solution increases the dissolution of phenolic compounds, which are initially part of the polymers or components connected to the cell wall [30-32].

The time variable, whose values were log-transformed for linearization, showed a positive linear effect, indicating that an increase in extraction time caused an increase in the content of extracted phenolic compounds. The extraction time should be sufficient for the solvent to dissolve the maximum possible amount of solute, until the system reaches equilibrium (saturation) [30]. Conversely, lengthy extraction times increase the possibility of oxidative degradation of the already extracted phenolic compounds, which is favored by high temperatures [33].

The effects of the temperature, $\mathrm{pH}$, and time variables on the concentration of phenolic compounds extracted from B. crassifolia leaves can be seen in the response surfaces (Figure 2), which were predicted by the empirical mathematical model generated shown in Equation 1. The mathematical model was validate and were used only significant factors ( $p$-value $<0.05$ ) in equation model generate.

$\mathrm{TP}=60.49+13.79 \mathrm{~T}-7.72 \mathrm{pH}-4.67 \log \mathrm{t}-7.47 \mathrm{~T}^{2}$ (equation 1 ), Where $\mathrm{TP}=$ total phenolic content, $\mathrm{T}=$ temperature $\left({ }^{\circ} \mathrm{C}\right)$, and $\log \mathrm{t}=\operatorname{logarithm}$ of time $(\mathrm{min})$.
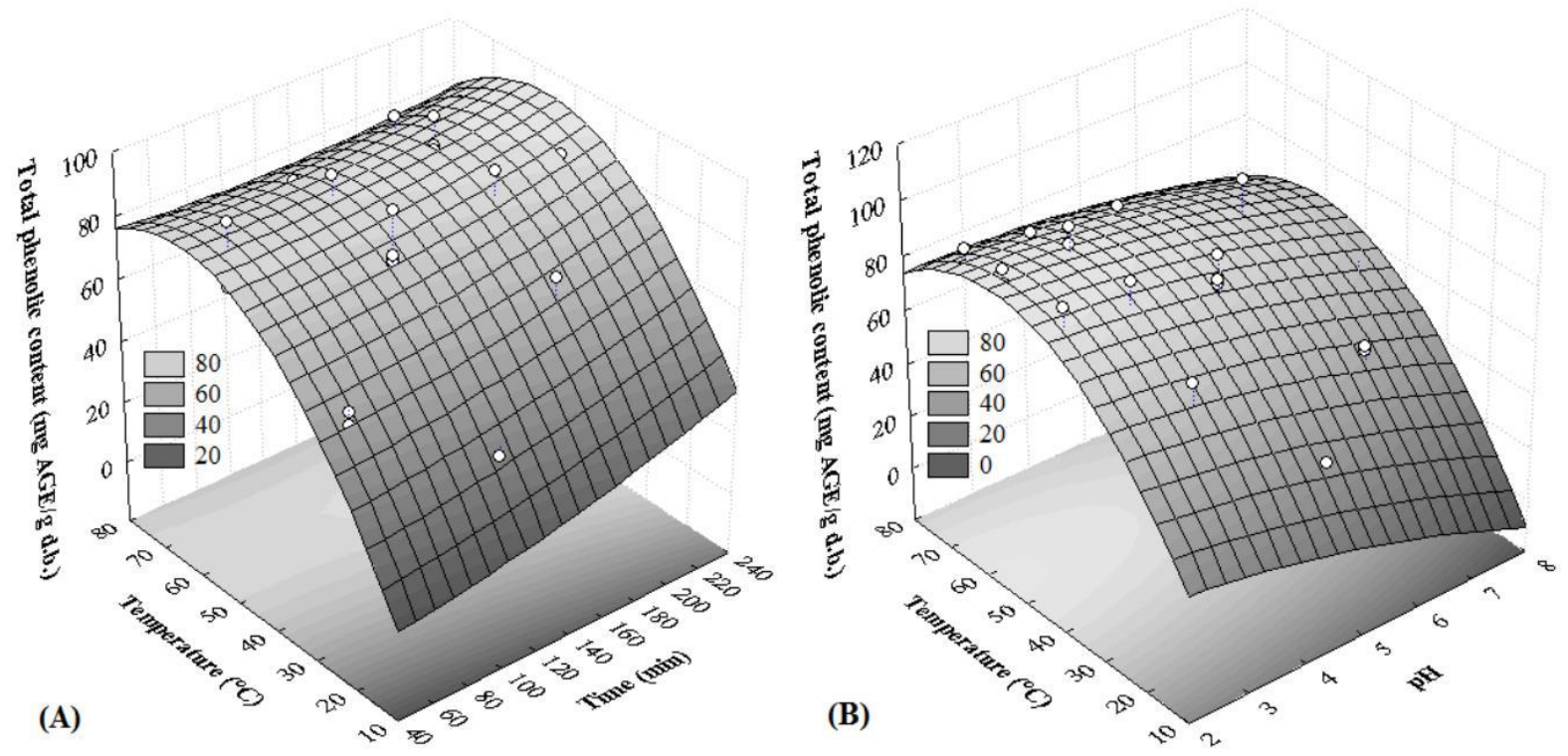

Figure. 2. Response surfaces for the total phenolic content of Byrsonima crassifolia leaves as a 3 function of temperature and time (A), or temperature and $\mathrm{pH}(B)$. (GAE: Gallic acid equivalent, d.b.: on dry basis).

The highest extraction efficiencies of total phenolic compounds are represented by the lighter areas in Figures $2 \mathrm{~A}$ and $2 \mathrm{~B}$ : temperatures between $45^{\circ} \mathrm{C}$ and $70^{\circ} \mathrm{C}, \mathrm{pH}$ between 2.0 and 4.5 , and extraction times longer than $200 \mathrm{~min}$. The maximum point for the effect of temperature was observed at approximately $60^{\circ} \mathrm{C}$. The extraction yield of phenolic compounds increases with temperature; however, some classes of flavonoids are thermosensitive (mainly anthocyanins and flavonoids derived from flavan-3-ols), which indicates the need to maintain the extraction temperature below the degradation limit [14, 30, 33].

Within the studied experimental field, and the conditions that showed the highest efficiencies of extraction, a temperature of $60^{\circ} \mathrm{C}, \mathrm{pH}$ of 4.5 , and a time of $220 \mathrm{~min}$ was established as the optimal 
conditions for the process. In these conditions, the concentration of total phenolic compounds extracted from $B$. crassifolia leaves, as predicted using Equation 1, was $90.65 \mathrm{mg} \mathrm{GAE} \mathrm{g}^{-1} \mathrm{DM}$. In the optimized conditions, the efficiency of enzymatic extraction was significantly higher than that in conventional solvent extraction, which is also performed under optimized conditions (73.28 $\mathrm{mg}$ GAE g ${ }^{-1} \mathrm{DM}$ ). A lower amount was reported by Souza et al. (2007) [34] (58.15 $\mathrm{mg} \mathrm{GAE} \mathrm{g}^{-1} \mathrm{DM}$ ) for extraction from $B$. crassifolia leaves by using a solution of methanol:water $(80: 20, \mathrm{v}: \mathrm{v})$ as the solvent.

Heemann et al. (2019) [35] verified for the enzymatic extraction of phenolic compounds from yerba mate, the optimum conditions of temperature of $50^{\circ} \mathrm{C}$, reaction time of 120 minutes and $\mathrm{pH}$ of 4.5, similar to the conditions verified in this work, which can be explained by the limitation of the conditions of use of the applied enzymes. Zhang et al. (2020) [36] showed that enzymatic extraction provided a more desirable profile of phenolic compounds with greater antioxidant activity, compared to other methods. According to Nogale-Bueno et al. (2020) [37] it is possible to obtain extracts with enzymatic extraction up to $120 \%$ more phenolic than those obtained by conventional methods, which shows that the application of this technology to products with a high phenolic content, such as Amazonian herbs, can be very interesting.

\section{CONCLUSION}

Generally and in this study, enzymatic extractions provided excellent yields of phenolic compounds from $B$. crassifolia leaves. The optimized conditions for enzymatic extraction were temperature $60^{\circ} \mathrm{C}, \mathrm{pH} 4.5$, and time $220 \mathrm{~min}$. Under these conditions, the concentration of extracted phenolic compounds was $90.65 \mathrm{mg} \mathrm{GAE} \mathrm{g}^{-1} \mathrm{DM}$, which was approximately $25 \%$ higher than that obtained by solvent extraction. Therefore, in general, enzymatic extraction is suggested as an alternative to conventional extraction using organic solvents for the extraction of phenolic compounds from leaves.

\section{REFERENCES}

1. Dweck AC. The internal and external use of medicinal plants. Clin Dermatol. 2009 Mar-Apr;27(2):14858. doi: 10.1016/j.clindermatol.2008.01.007.

2. Silva EM, Souza JNS, Rogez H, Rees, JF, Larondelle, Y. Antioxidant activities and polyphenolic contents of fifteen selected plant species from the Amazonian Region. Food Chem. 2007 Feb-Apr;101(3):10121018. doi:10.1016/j.foodchem.2006.02.055.

3. Ćujić N, Šavikin K, Janković T, Pljevljakušić D, Zdunić G, Ibrić, S. Optimization of polyphenols extraction from dried chokeberry using maceration as traditional technique. Food Chem. 2016 Aug;194: 135-142. doi:10.1016/j.foodchem.2015.08.008.

4. Latoui M, Aliakbarian B, Casazza AA, Seffen M, Converti, A, Perego, P. Extraction of phenolic compounds from Vitex agnus-castus L. Food Bioprod Process. 2012 Jan;90(4):748754. doi:10.1016/j.fbp.2012.01.003.

5. Da Porto C, Natolino, A. Supercritical fluid extraction of polyphenols from grape seed (Vitis vinifera): Study on process variables and kinetics. J Supercritical Fluids. 2017 Feb;130:239245. doi:10.1016/j.supflu.2017.02.013.

6. Chemat, F, Vian MA, Cravotto, G. Green Extraction of Natural Products: Concept and Principles. Int J Mol Sci. 2012 Jul;13(7):8615-8627. doi:10.3390/ijms13078615.

7. Macheix, JJ, Fleuriet, A, Billot, J. Fruit Phenolics. Montpellier, France: CRC press Taylor \& Francis; 1990. $361 \mathrm{p}$.

8. Puri M, Sharma D, Barrow CJ. Enzyme assisted extraction of bioactives from plants. Trends Biotechnol. 2012 Jan;30(1):37-44. doi: 10.1016/j.tibtech.2011.06.014.

9. Zhu Y, Li T, Fu X, Brennan M, Abbasi AM, Zheng BS, Liu RH. The use of an enzymatic extraction procedure for the enhancement of highland barley (Hordeum vulgare L.) phenolic and antioxidant compounds. Int J Food Sci Technol. 2016;51(8):1916-1924. doi:10.1111/ijfs.13165.

10. Weinberg ZG, Akiri B, Potoyevski E, Kanner J. Enhancement of polyphenol recovery from rosemary (Rosmarinus officinalis) and sage (Salvia officinalis) by enzyme-assisted ensiling (ENLAC). J Agric Food Chem. 1999;47:2959-2962. doi: 10.1021/jf981317.

11. Tomaz I, Maslov L, Stupić D, Preiner D, Ašperger D, Kontić JK. Recovery of flavonoids from grape skins by enzyme-assisted extraction. Sep Sci Technol. 2015;51(2):255-268. 10.1080/01496395.2015.1085881. 
12. Chen S, Xing XH, Huang JJ, Xu MS. Enzyme-assisted extraction of flavonoids from Ginkgo biloba leaves. Improvement effect of flavonol transglycosylation catalyzed by Penicillium decumbens cellulose. Enzyme Microb Technol. 2011 Jan;5;48(1):100-5. doi: 10.1016/j.enzmictec.2010.09.017.

13. Movagarnejad K, Sohrabi M, Kaghazchi T, Vahabzadeh F. A model for the rate of enzymatic hydrolysis of cellulose in heterogeneous solid-liquid systems. Biochem Eng J. 2000 Feb;4:197-206. doi: 10.1016/S1369-703X(99)00049-2.

14. Pinelo M, Tress AG, Pedersen MA, Meyer AS. Effect of cellulases, solvent type, and particle size distribution on the extraction of chlorogenic acid and other phenols from spent coffee grounds. Am. J. Food Technol. 2007 Jul;2:641-651. doi: 10.3923/ajft.2007.641.651.

15. Kammerer D, Claus A, Schieber A, Carle R. A novel process for the recovery of polyphenols from grape (Vitis vinifera L.) pomace. J Food Sci. 2005 Fev;70(2):157-163. doi: 10.1111/j.13652621.2005.tb07077.x.

16. Chamorro S, Viveros A, Alvarez I, Vega E, Brenes, A. Changes in polyphenol and polysaccharide content of grape seed extract and grape pomace after enzymatic treatment. Food Chem. 2012 May;133(2):308314. doi: 10.1016/j.foodchem.2012.01.031.

17. Silva EM, Rogez H, Larondelle Y. Optimization of extraction of phenolics from Inga edulis leaves using response surface methodology. Sep Purif Technol. 2007 Jul;55:381-387. doi: 10.1016/j.seppur.2007.01.008.

18. AOAC. Official methods of analysis of the Association of Official Analytical Chemists, sixteenth ed., Washington, 1997.

19. Silva DJ, Queiroz AC. Food analysis: chemical and biological methods. Third edition, UFV, Viçosa, MG, 2002. 235p.

20. Van Soest, PJ. Use of detergents in the analyses of fibrous feeds. II. A rapid method for determination of fiber and lignin. J Assoc Official Anal Chem. 1990 Jul;73:491-497, doi: 10.1093/jaoac/73.4.491.

21. McCready RM, McComb EA. Extraction and determination of total pectic materials in fruit, Anal. Chem. 1952 Dec 24, 1586-1588. doi.org/10.1021/ac60072a033.

22. Ghose TK. Measurement of cellulase activities. Pure Appl Chem. 1987;59:257-268. doi: $10.1351 /$ pac198759020257.

23. Miller GL. Use of dinitrosalicylic acid reagent for determination of reducing sugar. Anal Chem. 1959 Mar;31:426-428. doi: 10.1021/ac60147a030.

24. Bailey MJ, Biely P, Poutanem K. Interlaboratory testing of methods for assay of xylanase. J Biotechnol. 1992 May;23:257-270. doi: 10.1016/0168-1656(92)90074-J.

25. Santos SFM, Macedo GRI, Silva FLH, Souza RLA, Pinto GAS. Application of response surface methodology to study the production and the extraction of polygalacturonase. Quím Nova. 2008 Nov;31(8):1973-1978. doi: 10.1590/S0100-40422008000800010.

26. Rowley BI, Bull AT. Isolation of a yeast-lysing Arthrobacter species and the production of the lytic enzyme complex in batch and continuous-flow fermenters. Biotechnol Bioeng. 1977 Jan; 19:879-899. doi: 10.1002/bit.260190608.

27. Singleton VL, Orthofer R, Lamuela-Raventós RM. Analysis of total phenols and other oxidation substrates and antioxidants by means Folin-Ciocalteu reagent. Methods Enzymol. 1999 Jan;299:152-178. doi: 10.1016/S0076-6879(99)99017-1.

28. Esmelindro MC, Toniazzo G, Waczuk A, Dariva C, Oliveira D. Effects of industrial processing steps on the physico-chemical characteristics of mate tea leaves. Cienc Tecnol Aliment. 2002 Dec;22:193-204. doi: 10.1590/S0101-20612002000200016.

29. Modesti CF, Corrêa AD, Oliveira ED, Abreu CMP, Santos CD. Characterization of cassava leaf protein concentrate obtained by heat and acid precipitation. Cienc Tecnol Aliment. 2007 Jul;27:464-469. doi; 10.1590/S0101-20612007000300007.

30. Escribano-Bailón MT, Santos-Buelga, C. Polyphenol extraction from foods. Cambridge (UK): Royal Society of Chemistry; 2003. Chapter 1, Methods in Polyphenol Analysis; p.1-383, doi: 10.1021/np030739x.

31. Haki GD, Rakshit SK. Developments in industrially important thermostable enzymes: a review. Biores Technol. 2003 Aug;89(1):17-34, doi: 10.1016/s0960-8524(03)00033-6.

32. Chirinos R, Rogez H, Campos D, Pedreschi R, Larondelle Y. Optimization of extraction conditions of antioxidant phenolic compounds from mashua (Tropaeolum tuberosum) tubers. Sep Purif Technol. 2007 Nov;55(2):217-225. doi: 10.1016/j.seppur.2006.11.005.

33. Rajha HN, Darra NE, Hobaika Z, Boussetta N, Vorobiev E, Maroun RG, Louka N. Extraction of Total Phenolic Compounds, Flavonoids, Anthocyanins and Tannins from Grape Byproducts by Response Surface Methodology. Influence of Solid-Liquid Ratio, Particle Size, Time, Temperature and Solvent 
Mixtures on the Optimization Process. Food Nutr Sci. 2014 Feb;5(4):397-409. doi:10.4236/fns.2014.54048.

34. Souza JNS, Silva EM, Loir A, Rees JF, Rogez H, Larondelle Y. Antioxidant capacity of four polyphenolrich Amazonian plant extracts: a correlation study using chemical and biological in vitro assays. Food Chem. 2007 Jan;106(1):199-206. doi: 10.1016/j.foodchem.2007.05.011.

35. Heemann R, Kalegari, P; Spier MR, Santin E. Enzyme-assisted extraction of polyphenols from green yerba mate. Braz J Food Technol. 2019 May;22(1):1-10. doi: 10.1590/1981-6723.22217

36. Zhang YG, Kan H, Chen SX, Thakur K, Wang S, Zhang JG, Wei ZJ. Comparison of phenolic compounds extracted from Diaphragma juglandis fructus, walnut pellicle, and flowers of Juglans regia using methanol, ultrasonic wave, and enzyme assisted-extraction. Food Chem. 2020 Mar;321(1):1-9. doi:10.1016/j.foodchem.2020.126672

37. Nogales-Bueno J, Baca-Bocanegra B, Heredia FJ, Hernández-Hierro JM. Phenolic compounds extraction in enzymatic macerations of grape skins identified as low-level extractable total anthocyanin content. $\mathbf{J}$ Food Sci. 2020;1-8. doi:10.1111/1750-3841.15006 